\title{
Phytochemical Composition and Evaluation of Antimicrobial Activity of Blepharis linariifolia (Pers.) Seeds
}

\begin{abstract}
Alsiddig Osama $^{1 *}$, Sufyan Awadelkarim ${ }^{1}$, Noha Ali ${ }^{1}$, Safa Khalid ${ }^{1}$, Shima Mohammed ${ }^{1}$ and Nosiba Hashim ${ }^{1}$

${ }^{1}$ Department of Chemistry, Faculty of Science and Technology, Omdurman Islamic University, Sudan.

Authors' contributions

This work was carried out in collaboration between all authors. Authors AO and SA designed the study, performed the statistical analysis, wrote the protocol and the first draft of the manuscript. Authors NA, SK, SM and NH managed the analyses of the study. Author AO managed the literature searches. All authors read and approved the final manuscript.
\end{abstract}

Article Information

DOI: $10.9734 /$ AJOCS/2017/33182

Editor(s):

(1) Zygadlo Julio Alberto, Professor of Chemistry, National University of Cordoba, Argentina.

Reviewers:

(1) C.D.Dayanand, Sri Devaraj Urs academy of Higher Education and research, India.

(2) Fernanda Maria Marins Ocampos, Federal University of Paraná, Brazil.

Complete Peer review History: http://www.sciencedomain.org/review-history/19075

Original Research Article

Received $1^{\text {st }}$ April 2017

Accepted $16^{\text {th }}$ April 2017

Published $16^{\text {th }}$ May 2017

\section{ABSTRACT}

Blepharis linariifolia (Pers.) originates from Sudan and grows widely in Africa. The current study has been designed to evaluate the bioactive compounds and antimicrobial activity of the $n$-hexane extract of Blepharis linariifolia seeds. The extract was analyzed by GC-MS (Model GCMS-QP2010 Ultra, Shimadzu Co., Japan) which revealed the presence of 2-Pentanol, 2-methyl;3-Pentanol, 3methyl; 2-Hexanone; Hexanal; Benzaldehyde, 4-fluoro; 4-Methyl-4-(tetrahydropyran-2yl)oxypentane-2,3-dione; 4-methyl-4-[3',4',5',6'-tetrahydro-2'-H-pyranyl-2'-oxy]-2,3-pentanedione; Hexane, 1,1'-oxybis; 1-Pentanol, 2,2-dimethyl; Butanoic acid, 2-ethyl-2-methyl; 2-Heptene, 5-ethyl2,4-dimethyl; Undeca-4,8-dione; Acetic acid, 4-acetyl-2-isopropyl-5,5-dimethyltetrahydrofuran-2-yl ester; 1-(3,3-dimethyl-bicyclo[2.2.1]hept-2-yl)pentan-2-one 3-cyano-2-oxa-1-ethoxyadamanane; Ethyl 3-methyl-2-oxobutyrate; Heneicosane 4,8,12,16-Tetramethylheptadecan-4-olide; 1,2Benzenedicarboxylic acid, diisooctyl ester; Hexatriacontane and Dotriacontane. All compounds were identified from the spectral libraries of National Institute of Standard and Technology and WILEY. 
FTIR analysis revealed the presence various functional groups related to different type of organic substances including: Organic halogen, Ester, nitro compound, aromatics, amines, Aldehyde, Alkenes, Phenol, Alcohol and silicon compounds. The in vitro antimicrobial assays showed there is non-significant activity of this extract against five microorganism tested for.

Keywords: Blepharis linariifolia; oil; GCMS; FTIR; antimicrobial.

\section{INTRODUCTION}

Natural products are a well-known source of new valuable compound for medicinal or industry proposes [1]. Amongst the various natural sources, plants are predominant source of bioactive possess, including anticancer, antifungal and antimicrobial properties. The use of plant compounds as prototypes of new drugs has a historical and economic importance [2-3].

The analysis of plant extracts is extremely valuable to discover the chemical composition and to give better understanding of plant biological activities that may possess. Analysis of small amounts of chemicals has become easier and more and accurate after the discovery and development of chromatographic and spectroscopic techniques such as GC, HPLC, MS, NMR, etc. GC-MS are among the most powerful techniques used for both isolation and detection of samples which can be analyzed sufficiently even in trace amounts, less than $1 \mathrm{ng} / \mathrm{ml}$ [4].

Fourier Transform Infrared Spectrophotometer (FTIR) is perhaps the most powerful tool for identifying the types of chemical bonds (functional groups) present in compounds. The wavelength of light absorbed is characteristic of the chemical bond as can be seen in the annotated spectrum. By interpreting the infrared absorption spectrum, the chemical bonds in a molecule can be determined [5].

B. linariifolia (family: Acanthaceae) distributed in Africa especially the areas from Mauritania to Sudan, through Arabia to Northwestern India. B. linariifolia is a low-growing, wiry herb with prickly bracts and blue flowers. Seeds have analgesic activity and are also used in veterinary medicine [6]. However, genus Blepharis have not investigated much [7].

\section{MATERIALS AND METHODS}

\subsection{Extraction}

$B$. linariifolia seed samples were collected from River Nile state, Sudan. The fresh seeds were dried in shades for 7 days and then powdered then used for extraction. method was used as per the method described by Osama and Awdelkarim, [8].

\subsection{Fourier Transform Infrared Spec- trophotometer (FTIR) Analysis}

The above processed sample was used for FTIR analysis using $\mathrm{KBr}$ disk methodology. $1 \mathrm{mg}$ of sample was encapsulated in $100 \mathrm{mg}$ of $\mathrm{KBr}$ pellet in order to prepare translucent sample discs. The powdered sample was loaded in FTIR spectroscope (Shimadzu, IR Affinity 1, Japan), with a scan range from 400 to $4000 \mathrm{~cm}^{-1}$ with a resolution of $4 \mathrm{~cm}^{-1}$. Each analysis was repeated ten times for the spectrum confirmation.

\subsection{GC-MS Analysis}

GC-MS analysis was carried out by using the instrument (Model GCMS-QP2010 Ultra, Shimadzu Co., Japan) equipped with a capillary column Rtx-5 (0.25 $\mu \mathrm{m}$ film $\times 0.25 \mathrm{~mm}$ i.d. $\times 30$ $\mathrm{m}$ length). The instrument was operated in electron impact mode at ionization voltage (70 eV), injector temperature $\left(250^{\circ} \mathrm{C}\right)$, and detector temperature $\left(280^{\circ} \mathrm{C}\right)$. The carrier gas used was helium (99.9\% purity) at a flow rate of $1.2 \mathrm{~mL} / \mathrm{min}$ and about $1 \mu \mathrm{L}$ of the sample was injected. The oven temperature was initially programmed at $35^{\circ} \mathrm{C}(3 \mathrm{~min})$ to $240^{\circ} \mathrm{C}$ at $5^{\circ} \mathrm{C} / \mathrm{min}$ and from 240 $280^{\circ} \mathrm{C}$ at $3^{\circ} \mathrm{C} / \mathrm{min}$ withhold time up to 4 minutes. The identification of compounds from the spectral data was based on the available mass spectral records (NIST and WILEY libraries).

\subsection{Antimicrobial Evaluation}

\subsubsection{Preparation of bacterial suspensions}

One $\mathrm{ml}$ aliquots of pure standard bacteria of Bacillus subtilis, Staphylococcus aureus, Escherichia coli and Pseudomonas aeruginosa were aseptically distributed onto nutrient agar slopes and incubated at $37^{\circ} \mathrm{C}$ for 24 hours. The bacterial growth was harvested and washed off with $100 \mathrm{ml}$ sterile normal saline, to produce a suspension containing about 108- $109 \mathrm{cfu} / \mathrm{ml}$. 
The suspension was stored in a refrigerator at $4^{\circ} \mathrm{C}$ till used. The average number of viable organisms per $\mathrm{ml}$ of the stock suspension was determined by means of the surface viable counting technique. Serial dilutions of the stock suspension were made in sterile normal saline solution and $0.02 \mathrm{ml}$ volumes on drop of the appropriate dilutions were transferred by micro pipette onto the surface of dried nutrient agar plates. The plates were allowed to stand for two hours at room temperature for the drops to dry and then incubated at $37^{\circ} \mathrm{C}$ for 24 hours. After incubation, the number of developed colonies in each drop was counted. The average number of colonies per drop $(0.02 \mathrm{ml})$ was multiplied by 50 and by the dilution factor to give the viable count of the stock suspension, expressed as the number of colony forming units per $\mathrm{ml}$ suspension. Each time a fresh stock suspension was prepared. All the above experimental conditions were maintained constant so that suspensions with very close viable counts would be obtained.

\subsubsection{Preparation of fungal suspension}

The fungal cultures were maintained on Sabouraud dextrose agar, incubated at $25^{\circ} \mathrm{C}$ for 4 days. The fungal growth was harvested and washed with sterile normal saline and finally suspension in $100 \mathrm{ml}$ of sterile normal saline, and the suspension was stored in the refrigerator until used.

\subsubsection{In vitro testing of extracts for anti- microbial activity}

\section{A) Testing for Antibacterial Activity}

The cup-plate agar diffusion method was adopted according to published method of Eltayeb et al. [9] One $\mathrm{ml}$ of the standardized bacterial stock suspension $108-109$ C.F.U./ml were thoroughly mixed with $100 \mathrm{ml}$ of sterile molten nutrient agar which was maintained at $45^{\circ} \mathrm{C} .20 \mathrm{ml}$ aliquots of the inoculated nutrient agar were distributed into sterile Petri-dishes. The agars were left to dry and in each of these plates 4 cups ( $10 \mathrm{~mm}$ in diameter) were cut using a sterile cork borer (No. 4) and agar discs were removed. Alternate cups were filled with $0.1 \mathrm{ml}$ seed extract sample using automatic Microliterpipette, and allowed to diffuse at room temperature for two hours. The plates were then incubated in the upright position at $37^{\circ} \mathrm{C}$ for 18 hours. Two replicates were carried out for each extracts against each of the test organisms.
Simultaneously addition of extracts was carried out as controls. After incubation, the diameters of the resultants and growth inhibition zones were measured, averaged and the mean values were tabulated.

\section{B) Testing for Antifungal Activity}

The same method as for bacteria was adopted. Instead of nutrient agar, Sabouraud dextrose agar was used, which is considered to be more selective for fungal. The inoculated medium was incubated at $25^{\circ} \mathrm{C}$ for three days for Aspergillus niger.

\section{RESULTS AND DISCUSSION}

The n-hexane dissolved about $2.7 \%$ of total sample mass. Hexane is a nonpolar solvent capable to isolate the nonpolar compounds especially fatty acids, terpenes and steroids. This low yield percentage indicates the low amount of oil in this plant. The nature of sample is not the only factor that affect its content of group of compounds. The environmental factors, the part of plant used, methodology of extraction, duration of extraction, solvent used for extraction, etc. all these are factors can effect on percentage yield [10].

In the current study the hexane extract was analyzed using spectrometric techniques (FTIR and GCMS) to determine the functional groups and chemical constituents. The FTIR is the most powerful technique to determine the functional groups according to the response of compounds to the radiation with adjusted wave length. These groups are most likely responsible for the chemical and biological activities of this extract. The functional groups are the active parts of compounds they affect to its reactivity to certain kind of compounds or receptors. The study of the structure and its activities is the base of valuable part of medicinal chemistry which named as structure activity relationship [11]. The results showed the presence of different groups, shown in Table (1).

The functional groups detected by FTIR was mainly belong to aliphatic hydrocarbons, the highest absorption was found in 2958.6 (symmetric $\mathrm{C}-\mathrm{H}$ stretching) which indicates the high amount of hydrocarbons alkenes. The hydrocarbons are well known for their non-polar properties therefore they can be isolated by hexane, the solvent used for extraction. 
However, the alkenes are not active compounds compared to phenols or carboxylic acids. Low absorption was noticed for $\mathrm{OH}$ and $\mathrm{C}=\mathrm{O}$ groups which are known for their antimicrobial activity.

Gas chromatography- mass spectrometry is one of the most updated techniques to isolate and detected the volatile chemical substances. In the present study the GCMS analysis detect different kind of compounds with variable molecular weight. The chromatogram showed the presence of 22 compounds, which they were identified by MS. The MS showed that the molecular weight of these compounds which vary from 100 to 506 amu. These compounds are mainly aliphatic hydrocarbons, shown in Table (2).

The $B$. linariifolia seed extract was evaluated for its antimicrobial activity and was found to be inactive to five type of bacteria and fungal. Table (3). Compounds or plant extracts are considerd to be active if the inhbition zone excees $15 \mathrm{~mm}$ [12].

Table 1. Functional groups and its wave number

\begin{tabular}{lll}
\hline $\mathbf{C m}^{-1}$ & Bond & Functional Group \\
\hline 721.33 & C-X stretching $(\mathrm{X}=\mathrm{F}, \mathrm{Cl}, \mathrm{Br}$ or I) & organic halogen \\
1149.50 & Aliphatic $\mathrm{C}-\mathrm{O}$ stretching & Ester \\
1377.08 & Aliphatic $\mathrm{NO}_{2}$ symmetric stretching & nitro compound \\
1460.01 & $\mathrm{C}-\mathrm{C}$ stretching & (in-ring) aromatics \\
1537.16 & $\mathrm{~N}-\mathrm{O}$ asymmetric stretching & nitro compounds \\
1581.52 & $\mathrm{~N}-\mathrm{H}$ bend & $1^{\circ}$ amines \\
1668.31 & C=O stretching & carbonyls (general) \\
1822.61 & Overtone and combination bands & Other \\
2352.99 & Combination C-H stretching & Common near-infrared bands of \\
& & organic compounds \\
2731.02 & C-H stretching & Aldehyde \\
2866.02 & symmetric C-H stretching & Alkenes \\
2925.81 & asymmetric C-H stretching & Alkenes \\
2958.60 & symmetric C-H stretching & Alkenes \\
3544.92 & O-H stretching & Phenol \\
3589.28 & O-H stretching & Alcohol \\
3627.85 & O-H stretch & free hydroxyl alcohols, phenols \\
3652.93 & O-H stretch, & free hydroxyl alcohols, phenols \\
3670.28 & O-H stretching & free hydroxyl alcohols, phenols \\
3712.72 & O-H stretching & free hydroxyl alcohols, phenols \\
3780.22 & Si-OH stretching & silicon compounds \\
3876.65 & O-H stretching & free hydroxyl alcohols, phenols \\
3926.80 & O-H stretching & free hydroxyl alcohols, phenols \\
\hline
\end{tabular}

Table 2. GCMS analysis of $B$. linariifolia

\begin{tabular}{|c|c|c|c|c|c|}
\hline $\begin{array}{l}\text { Peak } \\
\text { no. }\end{array}$ & R. Time & $\begin{array}{l}\text { Area } \\
\%\end{array}$ & Compounded name & $\begin{array}{l}\text { Molecular } \\
\text { Formula }\end{array}$ & Mass \\
\hline 1 & 4.655 & 0.44 & 2-Pentanol, 2-methyl & $\mathrm{C}_{6} \mathrm{H}_{14} \mathrm{O}$ & 102 \\
\hline 2 & 5.157 & 0.22 & 3-Pentanol, 3-methyl & $\mathrm{C}_{6} \mathrm{H}_{14} \mathrm{O}$ & 102 \\
\hline 3 & 6.199 & 0.46 & 2-Hexanone & $: \mathrm{C}_{6} \mathrm{H}_{12} \mathrm{O}$ & 100 \\
\hline 4 & 6.474 & 0.72 & Hexanal & $\mathrm{C}_{6} \mathrm{H}_{12} \mathrm{O}$ & 100 \\
\hline 5 & 11.685 & 0.57 & Benzaldehyde, 4-fluoro & $\mathrm{C}_{7} \mathrm{H}_{5} \mathrm{FO}$ & 124 \\
\hline 6 & 19.309 & 0.50 & $\begin{array}{l}\text { 4-Methyl-4-(tetrahydropyran-2- } \\
\text { yl)oxypentane-2,3-dione }\end{array}$ & $\mathrm{C}_{11} \mathrm{H}_{18} \mathrm{O}_{4}$ & 214 \\
\hline 7 & 19.643 & 0.16 & $\begin{array}{l}\text { 4-methyl-4-[3',4',5',6'-tetrahydro-2'-H- } \\
\text { pyranyl-2'-oxy]-2,3-pentanedione }\end{array}$ & $\mathrm{C}_{11} \mathrm{H}_{18} \mathrm{O}_{4}$ & 214 \\
\hline 8 & 19.988 & 0.34 & Hexane, 1,1'-oxybis & $\mathrm{C}_{12} \mathrm{H}_{26} \mathrm{O}$ & 186 \\
\hline 9 & 20.064 & 0.19 & 1-Pentanol, 2,2-dimethyl & $\mathrm{C}_{7} \mathrm{H}_{16} \mathrm{O}$ & 116 \\
\hline 10 & 20.273 & 0.52 & Butanoic acid, 2-ethyl-2-methyl & $\mathrm{C}_{7} \mathrm{H}_{14} \mathrm{O}_{2}$ & 130 \\
\hline
\end{tabular}




\begin{tabular}{|c|c|c|c|c|c|}
\hline $\begin{array}{l}\text { Peak } \\
\text { no. }\end{array}$ & R. Time & $\begin{array}{l}\text { Area } \\
\%\end{array}$ & Compounded name & $\begin{array}{l}\text { Molecular } \\
\text { Formula }\end{array}$ & Mass \\
\hline 11 & 21.346 & 2.18 & 2-Heptene, 5-ethyl-2,4-dimethyl & $\mathrm{C}_{11} \mathrm{H}_{22}$ & 154 \\
\hline 12 & 23.226 & 1.94 & Undeca-4,8-dione & $\mathrm{C}_{11} \mathrm{H}_{20} \mathrm{O}_{2}$ & 184 \\
\hline 13 & 29.413 & 11.60 & $\begin{array}{l}\text { Acetic acid, 4-acetyl-2-isopropyl-5,5- } \\
\text { dimethyltetrahydrofuran-2-yl ester }\end{array}$ & $\mathrm{C}_{13} \mathrm{H}_{22} \mathrm{O}_{4}$ & 242 \\
\hline 14 & 31.695 & 3.10 & $\begin{array}{l}\text { 1-(3,3-dimethyl-bicyclo[2.2.1]hept-2- } \\
\text { yl)pentan-2-one }\end{array}$ & $\mathrm{C}_{14} \mathrm{H}_{24} \mathrm{O}$ & 208 \\
\hline 15 & 32.078 & 13.09 & 3-cyano-2-oxa-1-ethoxyadamanane & $\mathrm{C}_{12} \mathrm{H}_{17} \mathrm{NO}_{2}$ & 207 \\
\hline 16 & 34.041 & 15.49 & Ethyl 3-methyl-2-oxobutyrate & $\mathrm{C}_{7} \mathrm{H}_{12} \mathrm{O}_{3}$ & 144 \\
\hline 17 & 43.429 & 1.56 & Heneicosane & $\mathrm{C}_{21} \mathrm{H}_{44}$ & 296 \\
\hline 18 & 44.396 & 0.58 & 4,8,12,16-Tetramethylheptadecan-4-olide & $\mathrm{C}_{21} \mathrm{H}_{40} \mathrm{O}_{2}$ & 324 \\
\hline 19 & 46.706 & 2.13 & $\begin{array}{l}\text { 1,2-Benzenedicarboxylic acid, diisooctyl } \\
\text { ester }\end{array}$ & $\mathrm{C}_{24} \mathrm{H}_{38} \mathrm{O}_{4}$ & 390 \\
\hline 20 & 47.756 & 2.87 & Hexatriacontane & $\mathrm{C}_{36} \mathrm{H}_{74}$ & 506 \\
\hline 21 & 50.337 & 8.18 & Hexatriacontane & $\mathrm{C}_{36} \mathrm{H}_{74}$ & 506 \\
\hline 22 & 54.058 & 16.03 & Dotriacontane & $\mathrm{C}_{32} \mathrm{H}_{66}$ & 450 \\
\hline
\end{tabular}

Table 3. Antimicrobial evaluation of $B$. linariifolia against five standard organisms

\begin{tabular}{llllll}
\hline $\begin{array}{l}\text { Type of } \\
\text { microbe }\end{array}$ & \multicolumn{2}{l}{ Gram possitive } & Gram negative & Fungai \\
\cline { 2 - 6 } & $\begin{array}{l}\text { Bacillus } \\
\text { subtilis }\end{array}$ & $\begin{array}{l}\text { Staphylococcus } \\
\text { aureus }\end{array}$ & $\begin{array}{l}\text { Escherichia } \\
\text { coli }\end{array}$ & $\begin{array}{l}\text { Pseudomonas } \\
\text { aeruginosa }\end{array}$ & $\begin{array}{l}\text { Aspergillus } \\
\text { niger }\end{array}$ \\
\hline MDIZ $(\mathrm{mm})$ & 11 & 11.5 & 12 & 14 & zero \\
\hline \multicolumn{7}{c}{$M D I Z=$ mean diameter of growth inhibition zone }
\end{tabular}

\section{CONCLUSION}

Study concludes that, $B$. linarifolia seed extract contains different types of chemical compounds amongst major components were alkenes. bioactive compounds have minimal bactericidal and fungicidal activity. Further studies for both chemical and biological proposes are recommended.

\section{COMPETING INTERESTS}

Authors have declared that no competing interests exist.

\section{REFERENCES}

1. Zhao S, Liu JY, Chen SY, Shi LL, Liu YJ, Ma C. Antioxidant potential of polyphenols and tannins from burs of Castanea mollissima blume. Molecules. 2011;16: 8590-8600.

DOI: 10.3390/molecules 16108590

2. Mann J, Davidson RS, Hobbs JB, Banthorpe DV, Harborne JB. Natural Products. Their Chemistry and Biological Significance, Addison Wesley Longman, Harlow, UK; 1994.
3. Trease GE, Evans MD. A text book of Pharmacognosy, $13^{\text {th }}$ Edn. Baillier, Tindal and Caussel, London. 1989;144-148.

4. Prajna SS, Priya KS, Swarnalatha S, Bhojaraju P, Kanthal LK, Satyavathi K. GC-MS analysis and In-Vitro cytotoxic activity of methanolic extract of Antigonon Leptopus flowers. Int J Pharm Sci Res. 2015;6(7):3083-87.

DOI: 10.13040/IJPSR.0975-8232.6

5. Hollas JM. Modern spectroscopy. Fourth edition. John Wiley \& Sons. England; 2004.

6. Vijayalakshmi S, Kripa KG. Theraoutic uses of plants genus Blepharis- a systematic review. Int $\mathrm{J}$ Pharm Bio Sci. 2016;7(4):236-243.

7. Osama A, Awdelkarim S, Ezeldin M. Spectrophotometric determination of total phenol and flavonoid contents of aerial parts of Blepharis edulis (Pers.). Chem Sci Int J. 2017;18(2):1-7.

DOI: $10.9734 / C S I J / 2017 / 25916$

8. Osama A, Awdelkarim S. Phytochemical screening of Ficus sycomorus L. bark and Cleome gynandra L. aerial parts. J. Pharmacog. and Phytochem. 2015;4(4): 24-27.

9. Eltayeb OM, Jobara MI, Mohamed MA, Masaad AM, Elshikh AA, Elrofaei NA, 
Ahmed AO, FadulAllA EF, Mohamed AK. In vitro evaluation of antimicrobial, antioxidant activities and phytochemical screening of Quercus infectoria (galls) used in traditional medicine. Curr Res Microbiol Biotechnol. 2015;3(2):595-599.

10. Tiwari P, Kumar B, Kaur M, Kaur G, Kaur $\mathrm{H}$. Phytochemical screening and Extraction: A review. Internationale Pharmaceutica Sciencia. 2011;1:98-106.
11. Thomas G. Medicinal chemistry. $2^{\text {nd }}$ edition. John Wiley \& Sons Ltd. England; 2007.

12. Voukeng IK, Beng VP, Kuete V. Antibacterial activity of six medicinal Cameroonian plants against Gram-positive and Gram-negative multidrug resistant phenotypes. BMC Complement Altern Med. 2016;16:388.

DOI 10.1186/s12906-016-1371-y

(0) 2017 Osama et al.; This is an Open Access article distributed under the terms of the Creative Commons Attribution License (http://creativecommons.org/licenses/by/4.0), which permits unrestricted use, distribution, and reproduction in any medium, provided the original work is properly cited.

Peer-review history:

The peer review history for this paper can be accessed here: http://sciencedomain.org/review-history/19075 